\title{
FILOZOFICZNA MYŚL ROBERTA BOYLE'A A STANOWISKO CHRZEŚCIJAŃSKIEGO TEIZMU NATURALISTYCZNEGO
}

\begin{abstract}
Streszczenie. Robert Boyle jest autorem oryginalnej koncepcji mediacji pomiędzy sferą religii a nauki. W artykule przedstawiono wybrane elementy myśli filozoficznej Boyle'a, które wyznaczają jego ujęcie zagadnienia relacji wiara a nauka. W literaturze przedmiotu poglądy Boyle'a kwalifikuje się często jako przykład podejścia nazywanego „koncepcją dwóch ksiąg” albo „Boga jako zapchaj dziury". W artykule przedstawiono polemikę z tymi interpretacjami myśli Boyle’a i wskazuje się, że jego koncepcja jest bliska współczesnemu stanowisku chrześcijańskiego teizmu naturalistycznego.
\end{abstract}

Słowa kluczowe: Robert Boyle, wiara i nauka, naturalizm, naturalizm teistyczny, natura a kunszt

1. Wstęp. 2. Naturalizm a teizm naturalistyczny. 2.1. Stanowisko naturalizmu jako podstawa przyrodoznawstwa. 2.2. Główne założenia teizmu naturalistycznego. 3. Filozofia naturalna Roberta Boyle’a a teizm chrześcijański. 3.1. Główne założenia filozofii naturalnej Roberta Boyle’a. 3.2. Bóg, przyroda i filozofia naturalna Boyle'a. 4. Podsumowanie.

$\begin{array}{ll}\text { Radosław Kazibut } & \text { Uniwersytet im. Adama Mickiewicza w Poznaniu, } \\ \text { rkazibut@poczta.onet.pl } & \begin{array}{l}\text { Instytut Filozofii } \\ \text { Szamarzewskiego 89C, 60-568 Poznań }\end{array}\end{array}$




\section{WSTEPP}

Przestrzeń, w której dochodzi do styku refleksji podejmowanej przez człowieka na gruncie nauk przyrodniczych ze sferą ludzkiej wyznaniowości - rozumianej jako akt religijnej wiary - jest przedmiotem analiz zarówno filozofów, teologów, jak i przyrodoznawców. Z jednej strony twierdzi się, że spotkanie wiary (religii) z nauką prowadzi do nieuchronnego konfliktu, a wzajemne ewentualne oddziaływania obu tych obszarów ludzkiej aktywności, mają destrukcyjny wpływ na ich kondycję. Z drugiej strony można wskazać opinie podkreślające, że postulowany antagonizm jest pozorny, a ponadto obie sfery w pewien sposób się przenikają bądź są też wzajemnie komplementarne. W dziejach tradycji filozoficznej przekonanie o zachodzeniu sprzeczności między nauką a wiarą wyrażało się przede wszystkim na gruncie naturalizmu, a pogląd poszukujący możliwości mediacji pomiędzy obu sferami określany był mianem teizmu naturalistycznego.

Efektem wielkiej rewolucji naukowej XVII wieku było nie tylko ukształtowanie się nowożytnego paradygmatu poznania naukowego, ale także głęboka przemiana światopoglądowa. Dynamiczny postęp naukowy wymusił na badaczach - którzy w tamtym czasie niejednokrotnie byli zarazem przyrodoznawcami, filozofami i teologami - konieczność ponownego przemyślenia wydawałoby się dobrze wyeksplikowanych problemów, w tym także relacji pomiędzy nauką a wiarą. Jedną z głównych postaci tego okresu ,intelektualnej burzy" był Robert Boyle (1627-1691). Jest on powszechnie określany mianem ,ojca nowożytnej chemii", a tym samym jest jednym z najważniejszych koryfeuszy tego okresu. Dla Boyle'a zainteresowanie problemem relacji wiara a nauka wynikało nie tylko z potrzeby gorliwie wierzącego chrześcijanina, ale także z przekonania przyrodoznawcy, który uważał, że uprawiana przez niego nauka nie ma podstaw bez wiary w Boga ${ }^{1}$.

Badacze podejmujący się zadania dyskutowania relacji wiara a nauka często zbyt pochopnie kwalifikują poglądy Boyle'a na ten temat

J.J. Macintosh, Locke and Boyle on miracles and God's existence, w: Robert Boyle Reconsidered, red. M. Hunter, Cambridge 1994, 198. 
jako przykład stanowiska określanego mianem „teorii dwóch ksiąg” ${ }^{2}$. $\mathrm{Z}$ innej perspektywy argumentuje się, że jego przekonania wpisują się w związaną z XVII-wiecznymi przyrodoznawcami koncepcję „Boga jako zapychacza dziur"’3. Jednym z celów tego artykułu będzie polemika z tymi - w moim przekonaniu - uproszczonymi ujęciami zapatrywań Boyle'a na związki wiary i nauki. Przyznać trzeba, że trudno jest jednoznacznie zakwalifikować rozważania prowadzone na ten temat przez Boyle’a, gdyż są one bardzo złożone i wielopłaszczyznowe. Z ogromnej literatury przedmiotu poświęconej dorobkowi intelektualnemu Boyle'a wyłania się oryginalne i w wielu fragmentach wyprzedzające swoje czasy ujęcie tego intrygującego zagadnienia. Można postawić tezę, że Boyle'owskie poglądy na temat relacji nauka a wiara są w wielu aspektach zbieżne ze współcześnie utrzymywanym stanowiskiem teizmu naturalistycznego.

Aby zrealizować postawione powyżej zadanie, w pierwszej części artykułu przedstawię główne typy i założenia naturalizmu oraz stanowiska teizmu naturalistycznego - uchylając się od dyskutowania wszelakich problemów będących konsekwencją akceptowania tych filozoficznych koncepcji. W drugiej części zaprezentuję wybrane poglądy Roberta Boyle'a związane $\mathrm{z}$ dyskutowanym w artykule zagadnieniem, które szczególnie wpłynęły na kształt jego przekonań filozoficznych. W ostatniej części dokonam analizy przedstawionego materiału i sformułuję wnioski.

\section{NATURALIZM A TEIZM NATURALISTYCZNY}

Celem poniższego streszczenia głównych założeń naturalizmu i teizmu naturalistycznego nie jest eksponowanie tych elementów omawianych stanowisk filozoficznych, które są akcentowane przez przeciwników łączenia sfery wiary i nauki. Także, z drugiej strony, nie będę wydobywał tych tez, które w ocenie zwolenników takiej syntezy

2 S.J. Gulda, Skała wieków. Nauka i religia w petni życia, tłum. z ang. J. Bieron, Poznań 2002, 21-22.

3 E. McMullin, Ewolucja i stworzenie, tłum. z ang. J. Rodzeń, Kraków 1990, $42-50$. 
przemawiają za możliwością owocnej koegzystencji obu tych obszarów ludzkiej aktywności. Przedstawiony w tej części materiał - ze względu na ramy artykułu - nie będzie z całą pewnością pokazywał wszystkich aspektów obu omawianych stanowisk. Pozwoli jednakże na przedstawienie argumentów na rzecz postawionej we wstępie tezy o zbieżności Boyle’owskiego programu teizmu naturalistycznego ze współczesną odsłoną tego stanowiska filozoficznego.

\subsection{STANOWISKO NATURALIZMU JAKO PODSTAWA PRZYRODOZNAWSTWA}

W podręcznikach historii filozofii wskazuje się, że stanowisko naturalistyczne ma swoją genezę już w jońskiej filozofii przyrody. Wraz z rozwojem refleksji filozoficznej znalazło ono wyraz w wielu koncepcjach. Pogląd ten dyskutowany jest w kilku wersjach: filozoficznej, metafizycznej (względnie ontologicznej), metodologicznej (względnie epistemologicznej) i semantycznej ${ }^{4}$. Z perspektywy założonych w artykule rozważań mniej istotna jest płaszczyzna semantyczna i w związku z tym nie uwzględnię jej w dalszych rozważaniach.

Naturalizm filozoficzny jest blisko związany z filozofią pozytywistyczną, której istotę określają cztery reguły: fenomenalizm, nominalizm, odebranie wartości poznawczej sądom wartościującym i normatywnym oraz przekonanie o tym, że metody zdobywania wiedzy wartościowej poznawczo są tożsame dla wszystkich dziedzin doświadczenia ${ }^{5}$. W wyniku przyjęcia tych założeń uznano, że rezultaty rozważań metafizycznych, a także teologicznych zostają umieszczone poza zbiorem wiedzy wartościowej poznawczo, gdyż w tej refleksji nie respektuje się wskazanych powyżej reguł. Ustalone zostało swoiste kryterium demarkacji pomiędzy nauką a pseudonauką. W myśl tego podejścia refleksja filozoficzna ma uzasadnienie o tyle, o ile jest oparta

4 G. Bugajak, Problem naturalizmu w dialogu nauki i religii, w: Globalizácia ako platforma prieniku prírodných a humanitných vied. Nové formy komunikácie, red. J. Tiňo, Bratislava 2009, 37-53.

5 L. Kołakowski, Filozofia pozytywistyczna (Od Hume’a do Koła Wiedeńskiego), Warszawa 1966, 9-18. 
na wiedzy generowanej, przede wszystkim przez nauki przyrodnicze, które w najpełniejszy sposób miały spełniać założenia filozofii pozytywistycznej. W ten sposób naturalizm filozoficzny staje się tożsamy z naturalizmem naukowym, którego zwolennicy przyjmują, że wszystkie realne problemy podnoszone przez szeroko rozumianą refleksję filozoficzną muszą być rozwiązane na gruncie lub w oparciu o wiedzę z zakresu nauk przyrodniczych. Tak silne stanowisko redukcjonistyczne niekiedy osłabione jest do postaci umiarkowanego naturalizmu, którego zwolennicy nie odbierają niezależności refleksji filozoficznej od nauk przyrodniczych, ale podkreślają, że udzielane odpowiedzi na pytania filozoficzne nie mogą ignorować rozstrzygnięć nauk przyrodniczych ${ }^{6}$.

Zwolennicy naturalizmu naukowego de facto przyjmują, że całą wiedzę ludzką można zredukować do wiedzy fizykalnej. Tym samym tworzą swoistą ,piramidę epistemologiczną”, na szczycie której umieszczają fizykę, a ściślej rzecz biorąc - metody przyjmowane w ramach praktyki badawczej tej dyscypliny. Rozciągają w ten sposób idee naturalizmu naukowego na płaszczyznę metodologiczną. Stopień afirmacji ważności metod przyrodoznawstwa wyznacza postać skrajną i umiarkowaną naturalizmu metodologicznego. W ujęciu skrajnym przyjmuje się, że do wiedzy wartościowej poznawczo można tylko dotrzeć za pomocą metody nauk przyrodniczych, a niemożność ich stosowania dla jakiegoś obszaru intelektualnej aktywności człowieka pozbawia tę działalność statusu naukowości. Zwolennicy umiarkowanego naturalizmu metodologicznego utrzymują, że metody przyrodoznawstwa można aplikować do wszystkich obszarów badań. Bez względu na wskazaną powyżej różnicę, naturalista metodologiczny wygłosiłby swoiste ,credo postępowania badawczego": formułowane na gruncie danej dyscypliny twierdzenia muszą być bezapelacyjnie intersubiektywnie komunikowalne i sprawdzalne, a zakładane pojęcia deskryptywne muszą mieć empiryczne uzasadnienie ${ }^{7}$.

A. Lemańska, Filozofia przyrody a nauki przyrodnicze, Warszawa 1998, 152-163.

A. Pałubicka, Naturalizm i antynaturalizm, w: Filozofia a nauka. Zarys encyklopedyczny, red. Z. Cackowski, J. Kmita, K. Szaniawski, P.J. Smoczyński, Wrocław, Warszawa, Kraków, Gdańsk, Łódź 1987, 403-412. 
Konsekwencją - przytoczonych powyżej - zasad naukowości przyjmowanych przez naturalistów metodologicznych jest to, że na gruncie nauki można akceptować tylko te wyjaśnienia zjawisk świata przyrody, które oparte są na wskazaniu naturalnie zachodzących, pomiędzy badanymi zjawiskami, relacji przyczynowo-skutkowych. W tym aspekcie płaszczyzna metodologiczna stanowiska naturalistycznego przenika się z płaszczyzną ontologiczną, przyjmując postać naturalizmu ontologicznego lub metafizycznego. Pominę szereg subtelności związanych z interpretacją stanowiska naturalizmu ontologicznego. Zwrócę uwagę tylko na to, że także w tym kontekście jest symptomatyczny dla tej perspektywy redukcjonizm, który w zależności od stopnia głębi postulowanej redukcji przybiera postać stanowisk umiarkowanych i radykalnych. Zatem odpowiednio można wskazać na: naturalizm przyrodniczy - istnieje obiektywnie i niezależnie od naszych aktów poznawczych świat przyrody, który jest przedmiotem badań nauk przyrodniczych, naturalizm scjentystyczny - istnieje tylko to, co jest badane przez nauki przyrodnicze, oraz pogłębiony naturalizm scjentystyczny - głoszący, że istnieje to, czego istnienie postulują nauki przyrodnicze ${ }^{8}$.

Można przyjąć, że fundamentalnym założeniem wszystkich zwolenników stanowiska naturalistycznego - bez względu na akceptowany jego wariant - jest przekonanie o tym, że współczesne nauki przyrodnicze badają materialny świat przyrody, przede wszystkim za pomocą metod eksperymentalnych. Rezultatami tych prac są wyjaśnienia mechanizmów zachodzących w świecie przyrody, opierające się tylko na postulowaniu istnienia i oddziaływania zjawisk naturalnych oraz ich przyczyn. Zatem zainteresowania badaczy ukierunkowane są na odkrywanie i wyjaśnianie zależności przyczynowych, a nie na wyjaśnianie teleologiczne?

W związku z tym zwolennicy stanowiska teizmu naturalistycznego muszą wyeksplikować swój pogląd w taki sposób, aby nie dochodziło do sprzeczności pomiędzy deklarowaną przez nich wiarą w istnienie Boga-Stwórcy a zakładanym w nastawieniu naturalistycznym odrzuceniu

\footnotetext{
G. Bugajak, art. cyt., 48.

P. Bylica, Naturalizm nauk przyrodniczych a konflikt między nauka i religia, Kwartalnik Filozoficzny (2007)2, 147-159.
} 
tezy supranaturalizmu. Wydaje się, że jest to pod wieloma względami centralny problem podejmowanej próby syntezy teizmu i naturalizmu.

\subsection{GŁÓWNE ZAŁOŻENIA TEIZMU NATURALISTYCZNEGO}

Podobnie jak w przypadku referowania założeń naturalizmu, także charakteryzując stanowisko teizmu naturalistycznego, będę koncentrował się na krótkim streszczeniu jego głównych tez. Będę starał się unikać dyskutowania problemów filozoficznych wynikających z założeń tej koncepcji, chyba że wskazanie na daną kwestię będzie konieczne dla uchwycenia spójnego obrazu tego stanowiska. Dlatego też na wstępie zwrócę uwagę na pewną nieostrość terminologiczną związaną z potocznym synonimicznym użyciem terminu „wiara” i „religia”. We wstępie sygnalizowałem pewne dookreślenie tej relacji, odwołując się do pojęcia ,wyznaniowości”. Bezdyskusyjnym jest to, że pola znaczeniowe terminu „religia” $i$ „,wiara” nie są identyczne. Dlatego też należy odróżniać wiarę danej osoby, np. w istnienie Boga osobowego, od jego deklaracji przywiązania do danej religii, która powinna zakładać akceptację (wiarę) w przesłanie i dogmaty głoszone przez jego związek wyznaniowy. W tym świetle stanowisko teizmu naturalistycznego musi zakładać jakąś tożsamość pomiędzy wiarą a religią danej osoby, wyrażaną w akcie wyznania wiary w naukę danego związku wyznaniowego.

Jeżeli stanowisko teizmu naturalistycznego jest poglądem filozoficznym, to musi mieć uniwersalistyczną postać, tj. być możliwym do zaakceptowania przez każdego bez względu na deklarowaną przynależność do danego związku wyznaniowego. W związku z tym stanowisko teizmu naturalistycznego musi być „podwójnie neutralne światopoglądowo”. $\mathrm{Z}$ jednej strony $\mathrm{w}$ odniesieniu do nauki danego Kościoła, a $\mathrm{z}$ drugiej strony, aby respektować tezę o neutralności światopoglądowej wiedzy naukowej. W przekonaniu przeciwników tezy o komplementarności sfery wiary i nauki jest to opozycja nie do przezwyciężenia. Jednakże problemem pozostaje wskazanie zestawu minimalnych i koniecznych założeń teizmu naturalistycznego, które nie będą prowadzić do napięcia pomiędzy akceptacją tego stanowiska filozoficznego a wyznaniem wiary danego związku wyznaniowego. 
Teista naturalistyczny, tak jak każdy chrześcijanin, oczywiście przyjmuje istnienie Boga-Stwórcy i podziału rzeczywistości na sferę przyrodzoną - naturalną i nadprzyrodzoną. Tym, co cechuje teizm naturalistyczny, jest sposób widzenia aktywności Boga w świecie przyrody. Współcześni teiści naturalistyczni podkreślają swoistą jedność Boga i natury. „Boski Logos jest immanentnie obecny w całym procesie twórczego rozwoju wszechświata"10. Teza ta nie musi być przedmiotem krytyki ze strony naturalisty-ateisty. Może zostać zignorowana, gdyż jest tezą metafizyczną, która zgodnie z tradycją received view w filozofii nauki jest stwierdzeniem nienaukowym i jego ewentualna akceptacja nie wpływa na przebieg i rezultaty praktyki badawczej. Sytuacja ulega zmianie, kiedy spróbujemy udzielić odpowiedzi na pytanie: w jaki sposób przejawia się boska obecność w procesach zachodzących w świecie przyrody? Czy Bóg tylko biernie trwa w świecie przyrody? Czy może interweniuje w dzieje Wszechświata, wykorzystując w tym celu swoją wszechmoc sprawczą? Teiści naturalistyczni jednoznacznie odrzucają możliwość nadnaturalnego działania Boga w świecie - Bóg jest racjonalny. ,....) działania Boga w świecie nie należy sobie wyobrażać jako »antynaturalistycznych« - pchnięć czy nadzwyczajnych interwencji, lecz jako immanentną obecność w świecie i w jego prawach"11. Bóg nie tylko przejawia się w świecie przyrody, ale jest w swojej obecności aktywny, zatem wpływa na przebieg zjawisk przyrodniczych. Można zrekonstruować tok rozumowania teistów naturalistycznych w następujący sposób:

1. Bóg stworzył Wszechświat poprzez ustanowienie praw przyrody;

2. Bóg przejawia się w procesach zachodzących w świecie przyrody;

3. Bóg działa w świecie poprzez wykorzystywanie praw przyrody.

$\mathrm{Z}$ tych tez można wyciągnąć wniosek, że przyrodoznawstwo rozumiane jako badanie prawidłowości świata przyrody jest w pewien sposób ,podglądaniem Boga przy pracy”, a także swoistą formą poznania Absolutu. W moim przekonaniu wskazane tezy określają centralne założenia tego poglądu, gdyż można z nich wyprowadzić akceptowany

10 J. Życiński, Bóg i ewolucja. Podstawowe pytania ewolucjonizmu chrześcijańskiego, Lublin 2002, 56.

11 M. Heller, Naturalizm chrześcijański, Roczniki Filozoficzne 51(2003)3, 41-58. 
przez teistów naturalistycznych filozoficzny obraz poznania naukowego, a także pewne intuicje co do wpływu refleksji teologicznej na kształt wiedzy naukowej.

Teista naturalistyczny będzie twierdził, że stwórczy akt boski przesądza o tym, że prawidłowości świata przyrody wyrażone przez człowieka w postaci praw nauki istnieją w sposób niezależny od naszych aktów poznawczych, zatem są obiektywnymi stanami rzeczy w przyrodzie. Pomijając subtelności dyskusji epistemologicznej na temat źródeł i granic poznania, można stwierdzić, że teiści naturalistyczni zaakceptują stanowisko realizmu naukowego. Tradycyjnie w filozofii nauki przyjmuje się, że realizm naukowy pociąga za sobą realistyczne ujęcie teorii empirycznej. Jego zwolennicy odwołują się do argumentu z ,sukcesu nauki”, podkreślając kumulatywistyczny charakter rozwoju wiedzy naukowej oraz to, że centralną wartością sterującą poznaniem naukowym jest dążenie do odkrycia prawdy. Akceptowane przez badaczy teorie naukowe są przynajmniej aproksymacyjnie prawdziwe - w tym także przez lata budząca emocje, u wielu teistów chrześcijańskich, teoria ewolucji ${ }^{12}$. Wydaje się, że w syntezie teizmu i naturalizmu zakłada się, że metody nauk przyrodniczych w jakiś sposób mogą odzwierciedlać sposób postępowania Boga w świecie przyrody. Wyjaśnia to, w pewien teologiczny sposób, sukces nauki, a także zwrotnie potwierdza słuszność stanowiska naturalizmu metodologicznego. Powstaje pytanie: jak silną postać naturalizmu metodologicznego będą skłonni przyjmować teiści naturalistyczni?

Czy udane połączenie teizmu chrześcijańskiego i naturalizmu wyznacza zestaw dyrektyw, które prowadzą do rewizji poglądów akcentowanych na gruncie teologii i przyrodoznawstwa? Teiści naturalistyczni formułują właśnie kilka postulatów w odniesieniu do refleksji teologicznej. Przede wszystkim podkreśla się, że teologia powinna być uprawiana w duchu racjonalizmu, zawieszając ważność doświadczenia

12 Zakładając, że prawa teorii ewolucji są adekwatnymi opisami prawidłowości zachodzących w przyrodzie, to teoria ta jest ,prawdziwa” w sensie przyjmowanym przez realistów naukowych. W myśl przyjętych przez teistów naturalistycznych założeń, Bóg nie tylko stworzył prawidłowości przyrody, które opisują prawa wskazane na gruncie teorii ewolucji, ale ponadto ich nie łamie i działa z nimi w zgodzie. 
mistycznego. Doktryna teizmu chrześcijańskiego powinna uwzględniać rezultaty przyrodoznawstwa, a ocena rozumienia treści wiary musi być relatywizowana do danego okresu historycznego i kontekstu kulturowego ${ }^{13}$. W jaki sposób teizm może wpłynąć na sposób uprawiania nauk przyrodniczych? Oczywiście, przeciwnicy łączenia sfery wiary i nauki odpowiedzą na to pytanie, że tylko negatywnie, np. utratą neutralności światopoglądowej przez przyrodoznawstwo. Nie tak radykalni badacze będą wskazywać na fakt, że teizm wpływa na przyrodoznawstwo w ten sposób, że określa jego fundament aksjologiczny. Wartości te nie determinują bezpośrednio przebiegu samej praktyki badawczej przyrodoznawstwa, ale skutkują swoistym ograniczeniem swobody prowadzenia badań naukowych w postaci zakazów podejmowania tych badań, które mogą być uznawane za „,wchodzenie w kompetencje Boga”.

Można zastanawiać się, czy postulowana synteza teizmu i naturalizmu jest możliwa tylko i wyłącznie wtedy, kiedy zostanie przeprowadzona głęboka rewizja tez formułowanych na gruncie obu stanowisk filozoficznych. Sądzę, że sposób, w jaki Robert Boyle wiązał naturalizm z teizmem chrześcijańskim, jest przykładem połączenia, którego istotą i podstawą nie jest zderzenie przeciwieństw, ale wzajemne ich dopasowanie.

\section{FILOZOFIA NATURALNA ROBERTA BOYLE'A A TEIZM CHRZEŚCIJAŃSKI}

Robert Boyle był niezwykle płodnym badaczem. W jego intelektualnym dorobku znajdziemy prace, które są sprawozdaniami z jego prac eksperymentalnych oraz dyskusjami nad osiągniętymi w nich rezultatami, a także rozprawy poświęcone rozważaniom problemów filozoficznych i teologicznych. Ten szeroki wachlarz zainteresowań wpłynął na to, że Boyle konstruował złożone wywody, czerpiąc przesłanki ze wszystkich obszarów prowadzonych przez siebie rozważań.

13 P. Bylica, Glówne zalożenia i problemy teizmu naturalistycznego w sprawie relacji sfery nadprzyrodzonej $i$ świata przyrodniczego, w: Biosfera. Człowiek i jego środowisko $w$ aspekcie przyrodniczym, filozoficznym i teologicznym, red. W. Dyk, Szczecin 2012, 55-95. 
Jego styl argumentacyjny jest w pewien sposób eklektyczny. Jednak nie jest to efekt niepłodnych skłonności kompilatorskich, ale przekonania o tym, że refleksje - przyrodoznawcza, filozoficzna i teologiczna - są wzajemnie komplementarne. Wielopłaszczyznowość prowadzonych przez Boyle’a rozważań i argumentacji sprawia, że nie jest łatwo zwięźle streścić jego poglądy z zakresu filozofii przyrody. Przyjęte przeze mnie analityczne rozdzielenie dociekań Boyle'a na kwestie: metodologiczne, epistemologiczne i ontologiczne sprawia, że w dużym stopniu „ulatuje” subtelność jego argumentacji, ale z drugiej strony umożliwia zwięzłą rekapitulację jego poglądów. W pierwszej kolejności przedstawię te założenia myśli Boyle’a, które bezpośrednio związane są ze stanowiskiem naturalizmu, a następnie - dyskusje związane z jego teistycznymi przekonaniami.

\subsection{GŁÓWNE ZAŁOŻENIA FILOZOFII NATURALNEJ ROBERTA BOYLE’A}

Podstawowym metodologicznym założeniem filozofii naturalnej Roberta Boyle'a jest przekonanie, że przede wszystkim metody eksperymentalne dostarczają wiedzy wartościowej poznawczo ${ }^{14}$. Eksperymentalny styl Boyle'a wpisuje się w panującą $\mathrm{w}$ okresie rewolucji naukowej tendencję (ukształtowaną w przytłaczającym stopniu przez niego samego) równoczesnego prowadzenia szeroko zakrojonych prac nad wieloma problemami badawczymi ${ }^{15}$. Taka postawa przyrodoznawców tego okresu, dla których nie istniało pojęcie wąskiej specjalizacji, wynikała wprost z przekonania o jedności zjawisk świata przyrody, którego złożoność można uchwycić tylko przez badanie wszystkich przejawów danego zjawiska. $\mathrm{W}$ tym właśnie duchu uwidaczniają się kolejne cechy charakterystyczne eksperymentalizmu Boyle'a. W pierwszej kolejności jest to eklektyzm, który wynikał ze wskazanego powyżej

14 Eksperymentalistyczne poglądy Boyle’a kształtowały się przede wszystkim w nawiązaniu do myśli Francisa Bacona, ale także do średniowiecznej tradycji empiryzmu brytyjskiego oraz dociekań między innymi: Galileusza, Daniela Senerta, Georga Starkeya, Kartezjusza, Newtona.

15 U. Klein, Styles of Experimentation, w: Observation and Experiment in the Natural and Social Sciences, red. M.C. Galavotti, New York-Boston-Dordrecht-London-Moscow 2004, 159. 
stylu prowadzenia prac eksperymentalnych, a także z tego, że Boyle czerpał z kunsztu praktyków. Sięgał po wiedzę i umiejętności wypracowane w warsztatach alchemików i rzemieślników oraz z praktyki akuszerek, medyków i gospodyń domowych. Symptomatyczne w tym kontekście jest jego stwierdzenie, że więcej dowiedział się o strukturze drewna i kamieni od stolarzy oraz kamieniarzy niż z pism starożytnych myślicieli ${ }^{16}$. Kolejne elementy charakteryzujące eksperymentalny styl Boyle’a to elastyczność, ostrożność i krytycyzm ${ }^{17}$. Elastyczność wyrażała się w umiejętności aplikacji różnorodnej wiedzy i umiejętności do prowadzonych przez Boyle’a badań i w ogromnej pomysłowości w projektowaniu układów eksperymentalnych. Ostrożność i krytycyzm Boyle’a związane były z mitycznym i wręcz obsesyjnym powstrzymywaniem się przed formułowaniem zbyt pochopnych uogólnień. Programowo zakładał on, że baza empiryczna musi być maksymalnie jak najszersza i że nie można przeoczyć żadnego „eksperymentalnego tropu". Każdą informację należy skrupulatnie sprawdzić i zweryfikować w pracach laboratoryjnych.

Epistemologiczne założenia Boyle’owskiej filozofii są ściśle powiązane z jego wizją eksperymentalizmu. Podstawowe elementy to empiryzm, indukcjonizm i probabilistyczna koncepcja wiedzy. Centralną rolę w tym kontekście odgrywa jego teoria jakości i podział na jakości pierwotne - mechaniczne (kształt, wielkość, ruch i struktura) i na jakości wtórne - niemechaniczne, które są rezultatem zachodzenia oddziaływań mechanicznych. W rozumowaniach Boyle'a widoczne jest podejście redukcjonistyczne. Na podstawie eksperymentalnie stwierdzanych zależności z poziomu makroskopowego wyciągał wnioski o korpuskularnej strukturze materii. Wyodrębniał bezpośrednio obserwowalny poziom doświadczenia zmysłowego, niedostrzegalny poziom struktur

16 R. Boyle, Usefulness, II, sect. 2, Some Considerations touching the Usefulness of Experimental Naturall Philosophy. The Second Tome, Containing the latter Section Of the Second Part (1671), w: The Works of Robert Boyle, red. M. Hunter, E.B. Davis, London 1999, 444-445.

17 R.M. Sargent, The Diffident Naturalist. Robert Boyle and The Philosophy of Experiment, Chicago-London 1995, 215. 
korpuskularnych i najniższy poziom niedostrzegalnych elementów budujących cząsteczki materii ${ }^{18}$.

Z drugiej strony Boyle podkreślał, że ludzkie możliwości pojmowania są ograniczone. Istnieje wiele kwestii, które są niezrozumiałe, niewytłumaczalne i sprzeczne z ludzkim rozumem. Problem istoty nieskończoności jest niezrozumiałym dla ludzkiego umysłu, z kolei niewytłumaczalne są te zjawiska, dla których nie możemy wskazać przyczyn i mechanizmów ich zachodzenia. Natomiast w sytuacji, kiedy rozum ludzki dochodzi do sprzecznych wniosków, musi uznać jeden z nich, a drugi odrzucić - w przypadku przyrodoznawstwa pomocne są eksperymenty rozstrzygające ${ }^{19}$. Jest w tym podziale wyrażony zarówno Boyle'owski optymizm i sceptycyzm poznawczy. Wydaje się, że „sprzeczność” i „niewytłumaczalność” są przejściowymi aporiami ludzkiego rozumu. Rozwój filozofii naturalnej dostarcza, dzięki pracom eksperymentalnym, coraz więcej wiedzy o przyczynach i mechanizmach zjawisk świata przyrody. Ludzki umysł napotyka na granicę swoich możliwości, kiedy wykracza poza granice świata naturalnego.

Ontologiczną strukturę rzeczywistości Boyle charakteryzuje, odwołując się do hipotezy mechanistycznej lub korpuskularnej - operując tymi pojęciami jak synonimami. W tym porządku reguły organizacji materii na poziomie mikro przesądzają o własnościach makroskopowych substancji. Świat jest zbudowany z cząstek posiadających określone wielkości, kształty i struktury oraz posiadających atrybut ruchu. Zatem w najogólniejszym sformułowaniu - istnieje materia, w której naturze leży ruch ${ }^{20}$. Dzięki temu atrybutowi materia może być przekształcana, a procesy te są oddziaływaniami mechanicznymi. Boyle pisze: „W tym wielkim automacie świat jest jak zegarek lub zegar, w którym materia pozostawiona sama sobie i sama przez się nie mogła się na początku sama zorganizować w tak niezwykły mechanizm. Artysta umiejętnie go wykonał i ustalił zjawiska, określając ich kolejność, zakres, stosunek,

18 P. R. Anstey, The philosophy of Robert Boyle, London-New York 2000, 40-41.

19 J. Wojcik, Robert Boyle and the Limits of Reason, Cambridge 1997, 152-159.

20 R. Boyle, The Origin of Forms and Qualities. According to the Corpuscular Philosophy, w: Selected Philosophical Papers of Robert Boyle, red. M.A. Stewart, Indianapolis-Cambridge 1991, 18. 
kształt, ruch (jego próbę), spoczynek, zasady łączenia oraz inne dyspozycje mechaniczne - zgodnie z którymi działają sprężyny, koła, filary i inne części. Jednak to jeszcze nie wyjaśnia przyczyny istnienia tego zegara. Zatem musi istnieć coś, czego jeszcze nie znamy, coś co nie jest dostatecznie poznane" 21 . W tym świetle, poszukiwanie i wyjaśnianie związków przyczynowych jest głównym zadaniem przyrodoznawcy. Co jednak, gdy łańcuch przyczyn wyprowadza człowieka poza granice świata przyrody?

\subsection{BÓG, PRZYRODA I FILOZOFIA NATURALNA BOYLE'A}

W literaturze przedmiotu wskazuje się, że poglądy Boyle’a kształtowały się pod wpływem woluntaryzmu. Wszystko, co istnieje i zachodzi, jest wynikiem aktu woli Boga ${ }^{22}$. Wskazuje się też, że akceptował on podejście okazjonalistyczne zakładające, że każda przyczynowa interakcja materii wymaga interwencji Boga ${ }^{23}$. Wydaje się, że przyjęcie przez Boyle’a tych dwóch stanowisk całkowicie przekreślało możliwość „udanej” syntezy teizmu i naturalizmu w jego filozofii. Odwołanie się do woluntaryzmu, tradycyjnie przeciwstawianemu intelektualizmowi św. Tomasza z Akwinu, zdaje się oddalać możliwość racjonalnego uchwycenia relacji Boga i Natury. Z kolei okazjonalizm w radykalnym ujęciu przyjmował, że jedyną prawdziwą przyczyną wszystkiego jest Bóg. Z tej perspektywy poszukiwanie przez przyrodoznawców przyczyn zjawisk naturalnych jest zbędnym trudem. Jednak także w tym kontekście ujawnia się programowy sceptycyzm i krytycyzm Boyle’a, który doprowadził go do wypracowania własnej koncepcji.

Można powiedzieć, że główną ideą woluntaryzmu i okazjonalizmu jest głębokie przekonanie o nieograniczonej wszechmocy Boga. Także Boyle nie pozostawia w tej kwestii żadnych wątpliwości: „Bóg jest nieskończenie doskonały lub przynajmniej absolutnie doskonały, jest

21 Tamże, 71.

22 M.G. Cook, Divine Artifice and Natural Mechanism: Robert Boyle's Mechanical Philosophy of Nature, w: Science in Theistic Contexts Cognitive Dimensions, red. J.H. Brooke, M.J. Osler, J.M. van der Meer, Chicago 2001, 134.

23 P.R. Anstey, dz. cyt., 206. 
tak doskonały, jak tylko możemy sobie to wyobrazié" ${ }^{24}$. Jednak jak dowieść Jego istnienia? Boyle wylicza następujące argumenty na rzecz istnienia Boga: po pierwsze, bez odwołania się do Jego istnienia nie można stworzyć spójnego opisu świata; po drugie, fakt istnienia świata dowodzi istnienia projektanta; po trzecie, odwołuje się do argumentu ze złożoności świata przyrody oraz do faktu istnienia inteligentnych istot, który nie może być dziełem przypadku, ale celowego działania Stwórcy ${ }^{25}$.

Istnienie świata nie może być dziełem przypadku. Musi być rezultatem przemyślanego działania. Świat jest wielkim automatem, którego części i zasady działania określił jego Stwórca. „Maszyna ogromna, tak piękna, tak dobrze wymyślona i jednym słowem tak godna podziwu jak Świat, nie może być dziełem jedynie przypadku lub gwałtownego zderzania się i szczęśliwego nagromadzenia atomów, ale musi być stworzona przez Przyczynę niezwykle potężną, mądrą i dobroduszną"26. Ten sposób ujmowania struktury świata przyrody doskonale współgrał z rozwijaną w czasach Boyle'a koncepcją mechanicystyczną i korpuskularystyczną, które były recepcją myśli starożytnej, w szczególności myśli Epikura. Jednak pomimo przyjmowania ogólnych założeń tej perspektywy teoretycznej, Boyle nie akceptował zarówno ateizmu i utylitaryzmu Epikura, a w konsekwencji, wynikającego z tej filozofii, konfliktu pomiędzy sferą namysłu teologicznego a filozofią naturalną. Swoją koncepcję nazywał anaksagorejską i w ten sposób symbolicznie odcinał się zarówno od ateistycznych idei Epikura, jak i ujęcia Kartezjusza, który głosił, że Bóg określił tylko reguły oddziaływań materii, a wszelakie stworzenie powstało samorzutnie bez konieczności Jego ingerencji. Filozofia Anaksagorasa była bliższa intuicji Boyle’a, który podobnie, jak starożytny filozof dostrzegał boskie działanie na każdym etapie stworzenia. We wszystkim, co istnieje, miała być zawarta Opatrzność, trwała dyspozycja do „stwarzania się” w myśl określonego

24 R. Boyle, Royal Society Boyle Papers, 2, fol. 89.

25 J.J. Macintosh, art. cyt., 197-198.

26 R. Boyle, Christian Virtuoso, w: Works, red. M. Hunter, E.B. Davis, London 1999-2000, 299-300. 
celu $^{27}$. W świecie przyrody jawi się - w przekonaniu Boyle'a - celowość działań Boga. W tym kontekście Boyle po raz kolejny nawiązuje do filozofii starożytnej przez odwołanie się do arystotelesowskiego kryterium rozróżnienia istnienia z natury i z kunsztu. Stagiryta pisze w Fizyce: „Wśród rzeczy istniejących jedne istnieją z natury, drugie zaś wskutek innych przyczyn. Z natury istnieją zwierzęta i ich części oraz rośliny i ciała proste, jak ziemia, ogień, powietrze, woda (...). Okazuje się dalej, iż wszystkie wymienione rzeczy różnią się od tych, które nie są wytworami natury. Każdy bowiem tego rodzaju przedmiot nosi w sobie zasadę ruchu i spoczynku (...). Podobnie ma się sprawa z innymi sztucznymi wytworami; żaden z nich nie ma w sobie zasady swego własnego wytworzenia, lecz jedne mają tę zasadę w pewnych czynnikach zewnętrznych" ${ }^{28}$. Pomijając subtelności debaty nad kwestią 'naturalne' a 'sztuczne', można przyjąć, że Boyle odczytał arystotelesowskie kryterium w duchu myśli Awicenny, który przyjął, że naturalne i sztucznie wytworzone rzeczy z istoty są różne, a każdy wytwór kunsztu jest zawsze gorszy od naturalnego. Boyle polemizuje z perypatyczną koncepcją. W jego przekonaniu nie do zaakceptowania było to, że w istocie przyrody może być zawarta możliwość działania celowego, niezapośredniczonego w świadomym działaniu boskiego intelektu. Jak podkreśla to Margaret Cook, kolidowało to z jego teologicznymi przekonaniami. Boyle podkreślał, że świat został stworzony przez Boga z martwej materii. Materia jest bierna - jest tylko instrumentem w ,rękach" wszechwiedzącego i wszechmocnego Stwórcy, który ukształtował świat jako „cudowną” maszynę, pracującą według zasad mechaniki ${ }^{29}$. Można powiedzieć, że Boyle raczej reinterpretuje arystotelesowskie kryterium odróżnienia naturalnego od sztucznego. Celowość nie jest immanentną cechą świata przyrody, ale przejawia się w nim. W ten sposób zaciera się różnica pomiędzy dziełem Boga - światem przyrody a wytworem ludzkich rąk. W obu przypadkach „zasada stawania się” jest zawarta w jakimś czynniku zewnętrznym wobec materii, z której coś zostaje stworzone: dla przyrody jest nim Bóg, a dla artefaktów lu-

\footnotetext{
27 C. Wilson, Epicureanism at the Origins of Modernity, Oxford 2008, 225-226.

28 Arystoteles, Fizyka, tłum. z grec. K. Leśniak, Warszawa 2010, 87-88.

29 M.G. Cook, art. cyt., 143.
} 
dzie. Ten tok myślenia wyraża się w metaforze „boskiego rzemieślnika”. Jednak w tym kontekście pozostaje nierozstrzygnięty problem jakości rezultatów pracy „boskiego rzemieślnika” i człowieka. Boyle przyjmuje, że wytwór ludzkich rąk i to, co znajdujemy w świecie przyrody, nie różnią się od siebie $\mathrm{w}$ istocie, ale $\mathrm{w}$ przyczynie powstania. Unika „demiurgicznej pokusy" - zarzucanej często alchemikom - zrównania pracy Boga z pracą ludzkiego rzemieślnika, wskazując gradacje celowości działań - odróżnia: celowość uniwersalną, zawartą w konstrukcji wszechświata, w której wyraża się doskonałość Stwórcy; celowość kosmiczną albo systematyczną - w odniesieniu do sfery podksiężycowej i nadksiężycowej - odnoszącą się do ilości, kształtu, sposobów przekształcania się materii; celowość w budowie fizjologicznej organizmów żywych, a także ich usytuowania w ekosystemie; ostatnim typem są cele ludzkie ujęte $w$ aspekcie intelektualnym i materialnym ${ }^{30}$. Nietrudno się domyśleć, że pierwsze obszary są domeną działania Boga, a ludzkie wysiłki muszą naśladować reguły, które rządzą logiką stworzenia. Chociaż możliwości poznawcze człowieka są ograniczone i cel jego działań w konsekwencji także, to wiele jego wytworów nie ustępuje swoim naturalnym odpowiednikom. Boyle dokładnie opisuje prace syntetyczne nad uzyskaniem w laboratorium saletry potasowej i stwierdza, że „perypatyczne sztuczne działania” pozwalają uzyskać produkt identyczny z naturalnym pod względem wszystkich jakości ${ }^{31}$. Człowiek dzięki swoim umiejętnościom może wytworzyć to, co jest w naturze. Jest to możliwe, gdy działa według tych samych zasad, którymi kieruje się Bóg w swojej pracy. Bóg jest racjonalny w swoich działaniach i nie łamie praw, które określił, tworząc Wszechświat. Dlatego, że Bóg jest konsekwentny w tym zamyśle i działa, nie łamiąc ustalonych praw, to naturalista może badać i rozpoznawać obowiązujące w świecie prawidłowości przyrody. Stałość Opatrzności jest gwarancją tego, że prawa natury odzwierciedlają przewidywalne i powtarzalne prawidłowości

30 T. Shanahan, Teleological reasoning in Boyle's Disquisition about Final Causes, w: Robert Boyle Reconsidered, red. M. Hunter, Cambridge 1994, 180.

31 R. Boyle, A Physico-Chymical Essay, Containing an Experiment, with some Considerations touching the different parts and redintegration of Salt-Petre, w: Works,1 red. T. Brinch, London 1772, 359-376. 
zachodzące w przyrodzie. Ze względu na ograniczone możliwości poznawcze człowiek niektóre działania Boga w świecie rozpoznaje jako cudowne Jego ingerencje. Jednak pomimo tego, że możliwości boskie są nieograniczone, to według Boyle’a Bóg zawsze przestrzega praw, które ustalił. Cnotliwy chrześcijanin i naturalista musi przyjąć, że wszystkie prawidłowości i osobliwości, które dostrzega, są wytłumaczalnymi oddziaływaniami mechanicznymi, które on może badać. Boyle stwierdza: „zamiast dzielić działalność Boga, na dwa typy - naturalne i nadprzyrodzone; to myślę, że możemy przyjąć trzy typy i dzielić te operacje na nadprzyrodzone, naturalne sensu stricto, to jest mechaniczne, i naturalne sensu largo, które nazywam supramechanicznymi" 32 .

Podsumowując, można uznać, że Boyle relację pomiędzy Bogiem a światem ujmuje w czterech aspektach. Po pierwsze, Bóg jest stworzycielem świata, który powstał w wyniku aktu Jego woli. Po drugie, Jego obecność w świecie przejawia się w prawach natury, zgodnie z którymi stworzył Świat. Zachodzi swoista jedność pomiędzy światem stworzonym a Bogiem, ale nie w panteistycznym sensie. Jedność ta wyraża się w regułach, które organizują świat przyrody. Ponadto Bóg jest obecny w każdym etapie tworzenia, gdyż nic bez Jego woli nie może powstać ani zginąć, i w ten sposób podtrzymuje świat w jego istnieniu. Bóg jest racjonalistą i ,unika" uciekania się do swoich nadprzyrodzonych możliwości, a jeżeli już to tylko akcydentalnie w odniesieniu do zdarzeń lokalnych. Fakt, że Bóg przestrzega ustalonych praw, pozwala naturaliście dostrzegać i badać prawidłowości świata przyrody.

Wydaje się, że zarysowany powyżej Boyle’owski program syntezy naturalizmu i teizmu w dużym stopniu wpisuje się we współczesne propozycje teistów naturalistycznych. W tym miejscu, przejdę do wyliczenia tych elementów, które niewątpliwie można uznać za wspólne dla obu koncepcji połączenia sfery naukowości i wyznaniowości, a także zwrócę uwagę na pewne istotne rozbieżności.

32 R. Boyle, Christian Virtuoso, II, Works, vi, red. T. Brinch, London 1772, 754. 


\section{PODSUMOWANIE}

Na podstawie przedstawionego powyżej materiału można bezdyskusyjnie uznać, że Robert Boyle należał do grona tych luminarzy nauki, którzy nie tylko widzieli możliwość mediacji pomiędzy sferą wiary a nauki, ale także konieczność głębokiej syntezy obu tych obszarów.

W XVII wieku w dalszym ciągu była popularna tzw. koncepcja dwóch ksiąg. Zgodnie z nią Bóg w swojej wszechmocy i nieomylności nie dopuściłby do realnej sprzeczności pomiędzy tym, co zachodzi w świecie przyrody, a objawieniem zawartym w Biblii. Zatem dostrzegana przez człowieka sprzeczność między księgą Natury a Biblią miała być wynikiem błędnego zinterpretowania jednej bądź obu ksiąg. Zadawano sobie pytanie: którą z ksiąg człowiek źle odczytał? Zwolennicy wyższości orzeczeń zawartych w Biblii nad werdyktami nauki, tzw. fundamentaliści, uznają, że ewentualny konflikt można usunąć poprzez reinterpretację poglądów naukowych. Przeciwny pogląd głoszą konkordyści, którzy podkreślają, że Biblia jako tekst natchniony ma charakter metaforyczny i nie wszystkie jej fragmenty mogą być interpretowane dosłownie. A właśnie literalna interpretacja niektórych newralgicznych części Biblii prowadzi do - de facto pozornego - konfliktu między wiarą a nauką. Czy Roberta Boyle’a można uznać za zwolennika koncepcji dwóch ksiąg? W eseju z 1650 roku pt. Of the Study of the Booke of Nature Boyle pisze o trzech księgach, które są wiarygodnym źródłem wiedzy o świecie - są to księgi: Natury, Biblii i Sumienia ${ }^{33}$. Można suponować, że u Boyle’a księga Sumienia określa obszar, na którym dochodzi do stwierdzenia i rozstrzygnięcia konfliktu pomiędzy wiarą a nauką. Sumienie filozofa, które prowadzi go na drodze poszukiwania prawdy, obiektywność przyrodoznawcy wobec faktów niezbitych oraz cnoty chrześcijanina określają fundament aksjologiczny filozofii naturalnej Boyle’a. Zatem czy Boyle’a można uznać za konkordystę czy fundamentalistę? W zależności od założonej optyki można ocenić, że Boyle w tym względzie jest bardzo niekonsekwentny lub po raz kolejny oryginalny. Kluczowy jest w tym kontekście sposób interpretowania przez

33 R. Boyle, [O]f the Study of the Booke of Nature, w: Letters and Papers of Robert Boyle, red. P. L. Kesaris, London 1990, 8, 123-139. 
Boyle'a Biblii. Trudno jednoznacznie orzec czy odczytywał jej tekst literalnie, czy metaforycznie. Chociaż Boyle pisze: „nie widzę podstaw do przyjęcia opinii, żeby patrzeć na dwa pierwsze rozdziały Księgi Rodzaju tylko alegorycznie, odrzucając ich dosłowne i historyczne rozumienie"34. Wydaje się, że przytoczony fragment nie powinien pozostawiać wątpliwości. Jednak, jak zauważa Jana Wojcik, Boyle traktował tekst biblijny jako wskazówkę, a nie jako gotowe rozwiązanie jakiejś kwestii. W ten sposób oddalał, według niego, mylne przekonanie „epikurejczyków” o możliwości powstania człowieka w wyniku kosmicznego zbiegu okoliczności, przywołując słowa Księgi Genesis opisujące stworzenie człowieka przez Boga. W ten sam sposób odpierał tezę o wiecznym istnieniu świata, wskazując na tekst Apokalipsy św. Jana ${ }^{35}$. Przypomnę, że Boyle'a uznaje się za woluntarystę, zatem można stwierdzić, że dla niego wszystkie zdarzenia zachodzące w świecie są rezultatem boskiej interwencji, nic nie dzieje się bez Jego woli. Oczywiście, uchylam się od dyskutowania problemów natury filozoficznej, a także teologicznej, związanych z utrzymywaniem takiego stanowiska, chcę tylko zwrócić uwagę na to, że w ten sposób Boyle zacierał różnice między działaniem Boga w sposób nadprzyrodzony i z wykorzystaniem zjawisk naturalnych. Wszystko, co istnieje, jest dziełem Boga, zatem w swoim źródle jest nadnaturalne. Świat jest cudem Boga. Można powiedzieć, że jest to ukryta taktyka ,zalepiania Bogiem” luk w ludzkiej wiedzy. Tam, gdzie Boyle nie może na gruncie naturalizmu metodologicznego rozstrzygnąć spornej kwestii, wprowadza „tylnymi drzwiami” mechanizm ingerencji Boga. J.J. Macintosh argumentuje, że Boyle rozumiał mechanizm boskiej interwencji w świat jako przykład działania cudownego, ale takiego, w którym Bóg nie wykorzystuje swoich nadprzyrodzonych mocy. Świat przyrody jest dla Boyle’a królestwem, które może być wyjaśnione naukowo, chociaż są w nim zjawiska, które wymagały boskiej interwencji, np. relacja psychofizyczna. Jednakże wszystkie istniejące zależności mają charakter oddziaływań mechanicznych i tylko w akcie kreacji potrzebna była cudowna interwencja Boga. Od momentu stwo-

34 R. Boyle, The excellency of theology compared with natural philosophy, w: Works, red. T. Brinch, London 1772, 11.

35 J. Wojcik, dz. cyt., 140. 
rzenia Świata Bóg działa zgodnie z określonymi przez siebie regułami mechaniki, zatem zdarzenia cudowne rozumiane jako nadnaturalne boskie pchnięcie, miały miejsce tylko lokalnie na początku stworzenia ${ }^{36}$. W tym świetle nie można zarzucić Boyle’owi, że odwołuje się do aktu boskiej ingerencji, kiedy nie może wytłumaczyć jakiś faktów. Zakłada on z góry, że ludzki rozum napotka na takie problemy, które przekroczą jego możliwości poznawcze. Jednak jego przekonanie o istnieniu Boga nie wynika z potrzeby ,zapychania nim dziur” w wiedzy o świecie, ale z przyjętego światopoglądu. Teizm Boyle’a nie wynikał z potrzeby rozwiązania problemu epistemologicznego - chociaż podkreśla, że opis świata bez Boga jest niekompletny - ale głębokiej jego wiary. Miał świadomość tego, że epikurejski ateizm nie jest wewnętrznie sprzeczny i można go utrzymywać, akceptując założenie o nieplanowanym a losowym powstaniu Wszechświata.

Odwołując się do terminologii zaproponowanej przez Kazimierza Jodkowskiego uważam, że Robertowi Boyle'owi udało się wypracować taki epistemiczny układ odniesienia, który z jednej strony zachowywał u swojej podstawy naturalizm metodologiczny, a z drugiej strony w konsekwencji nie prowadził do konfliktu między wiarą a nauką. Jodkowski podkreśla, że podstawowym punktem ,zapalnym w relacji nauka a wiara jest konieczność akceptowania przez teistów faktu zachodzenia w świecie zdarzeń cudownych, których istnienia na gruncie nowożytnego paradygmatu poznania naukowego nie można utrzymywać"37. Boyle'owi udało się przezwyciężyć ten problem przez dokonanie swoistej reinterpretacji pojęcia zdarzenia cudownego i sposobu rozumienia, w jaki sposób Bóg może ingerować w tok zdarzeń ziemskich. Przede wszystkim należy zwrócić uwagę, że właściwie przeniósł ciężar dowodu w tym sporze na epikurejczyków, wskazując, że prawdopodobieństwo powstania świata w wyniku losowego i przypadkowego połączenia atomów w większym stopniu wykazuje znamiona zdarzenia cudownego, niż przyjęcie za pewnik, że Wszechświat powstał w wyniku celowego działania. Ponadto zachodzące w przyrodzie prawidłowości nie są cu-

\footnotetext{
36 J.J. Macintosh, art. cyt., 206.

37 K. Jodkowski, Spór ewolucjonizmu z kreacjonizmem. Podstawowe pojęcia i poglądy, Wydawnictwo Megas, Warszawa 2007, 180.
} 
downe dlatego, że są wynikiem nadnaturalnego boskiego działania, ale dlatego, że prawa mechanik, które określają ich naturę, są dobre, doskonałe $\mathrm{w}$ swojej prostocie i po prostu piękne ${ }^{38}$. Z tego punktu widzenia propozycja Boyle'a jest bardzo podobna do tez formułowanych przez teistów naturalistycznych, którzy „cudowność” interpretują w podobny sposób - jako możliwość ingerencji Boga w przebieg zdarzeń poprzez stosowanie praw przyrody. Wydaje się, że Boyle utrzymywałby, że z perspektywy metodologii naturalistycznej zjawiska będące wynikiem aktu boskiej ingerencji - jak na przykład oddziaływanie między umysłem a ciałem - mogą być badane bez żadnych przeszkód na gruncie naturalistycznym właśnie dlatego, że oparte są na prawach mechaniki. Biorąc również pod uwagę - wskazywane przez Boyle'a - naturalne ludzkie ograniczenia poznawcze, nie ma możliwości, by na gruncie naturalistycznego warsztatu badawczego można było odróżnić zjawiska zachodzące w wyniku boskiej interwencji z wykorzystaniem praw natury od zjawisk przebiegających w sposób „,naturalny”, tj. bez bezpośredniego zaangażowania Boga.

Można zarzucić propozycji Boyle’a to, że postulowana reinterpretacja pojęcia „cudowności” jest właściwie tylko retoryczną sztuczką, która u podstawy zakłada to, że na początku stworzenia doszło do nadprzyrodzonego, boskiego pierwszego pchnięcia. Pojęcie ,zdarzenia cudownego" opierające się na akcie nadprzyrodzonego działania nie odnosi się do cudów, tylko do zjawisk naturalnych. Zatem, w jakimś sensie, zainicjowanie warunków początkowych dla zaistnienia Świata nie jest zjawiskiem naturalnym. Jednak Boyle nie ukrywa tego problemu, broniąc odrzuconej w jego czasach, przez większość luminarzy nowożytnej nauki, zasady celowości. Można również postawić Boylowi zarzut niekonsekwencji, kiedy utrzymuje, że istnieją zjawiska, których zrozumienie wykracza poza poznawcze możliwości ludzkiego rozumu. Czy to oznacza, że nie wszystkie zjawiska świata przyrody można zrozumieć, opierając się na prawidłach mechaniki? Być może to założenie skłoniło Boyle’a do utrzymywania probabilistycznej koncepcji wiedzy

38 R. Boyle, About the Exellency and Grounds of the Mechanical Hypothesis, w: Selected Philosophical Papers of Robert Boyle, red. M.A. Stewart, Cambridge 1991, 138-141. 
i swoistego aproksymacyjnego podejścia do prawdziwości wiedzy naukowej. Można metaforycznie powiedzieć, że Boyle przezwyciężył w swoim przekonaniu problem konfliktu pomiędzy nauką a wiarą, uznając, że Bóg w odniesieniu do zdarzeń zachodzących w świecie przyrody przyjął epistemiczny układ odniesienia, oparty na naturalizmie. Po prostu jest naturalistą i przyrodoznawcą, z tą tylko różnicą, że posiada pełną wiedzę o mechanizmach świata przyrody, którą człowiek musi dopiero odkryć.

\section{BIBLIOGRAFIA}

Anstey P. R., The Philosophy of Robert Boyle, Routledge, London-New York 2000.

Arystoteles, Fizyka, tłum. z grec. K. Leśniak, Warszawa 2010.

Boyle R., The Excellency of Theology Compared with Natural Philosophy, w: The Works of the Honourable Robert Boyle, red. T. Birch, London 1772.

Boyle R., About the Exellency and Grounds of the Mechanical Hypothesis, w: Selected Philosophical Papers of Robert Boyle, red. M.A. Stewart, Hackett Publishing Company Cambridge 1991, 138-154.

Boyle R., The Origin of Forms and Qualities. According to the Corpuscular Philosophy, w: Selected Philosophical Papers of Robert Boyle, red. M.A. Stewart, Hackett Publishing Company, Indianapolis-Cambridge 1991, 1-96.

Boyle R., Royal Society Boyle Papers, 2, fol. 89, (http://www.bbk.ac.uk/boyle/boyle_papers/boylepapers_index.htm).

Boyle R., Christian Virtuoso, w: Works, red. M. Hunter, E.B. Davis, Pickering and Chatto, London 1999-2000.

Boyle R., Usefulness, II, sect. 2, Some Considerations touching the Usefulness of Experimental Natural Philosophy. The Second Tome, Containing the latter Section Of the Second Part (1671), w: The Works of Robert Boyle, red. M. Hunter, E.B. Davis, Pickering and Chatto, London 1999-2000.

Boyle R., [O]f the Study of the Booke of Nature, w: Letters and Papers of Robert Boyle, red. P.L. Kesaris, A microfilm project of University Publications of America, London 1990, 8. 
Bugajak G., Problem naturalizmu $w$ dialogu nauki i religii, w: Globalizácia ako platforma prieniku prírodných a humanitných vied. Nové formy komunikácie, red. J. Tiňo, Wyd: Ústredie Slovenskej Krestanskej Inteligencie, Bratislava 2009, 37-53.

Bylica P., Naturalizm nauk przyrodniczych a konflikt między nauka i religia, Kwartalnik Filozoficzny (2007)2, 147-159.

Bylica P., Główne założenia i problemy teizmu naturalistycznego $w$ sprawie relacji sfery nadprzyrodzonej $i$ świata przyrodniczego, w: Biosfera. Człowiek i jego środowisko w aspekcie przyrodniczym, filozoficznym i teologicznym, red. W. Dyk, Wydawnictwo Naukowe Uniwersytetu Szczecińskiego, Szczecin 2012, 55-95.

Cook M. G., Divine Artifice and Natural Mechanism: Robert Boyle's Mechanical Philosophy of Nature, w: Science in Theistic Contexts Cognitive Dimensions, red. J.H. Brooke, M.J. Osler, J.M. van der Meer, Wyd. Osiris, Chicago 2001, 133-151.

Gulda S.J., Skała wieków. Nauka i religia w pełni życia, tłum. z ang. J. Bieroń, Wyd. Zysk i Ska, Poznań 2002.

Heller M., Naturalizm chrześcijański, Roczniki Filozoficzne 51(2003)3, 41-58.

Jodkowski K., Spór ewolucjonizmu z kreacjonizmem. Podstawowe pojecia i poglądy, Wyd. MEGAS, Warszawa 2007.

Klein U., Styles of Experimentation, w: Observation and Experiment in the Natural and Social Sciences, red. M.C. Galavotti, Boston Studies In The Philosophy Of Science, Vol. 232, Kluwer Academic Publishers, New York-Boston-Dordrecht-London-Moscow 2004, 159-186.

Kołakowski L., Filozofia pozytywistyczna (Od Hume’a do Koła Wiedeńskiego), PWN, Warszawa 1966, 9-18.

Lemańska A., Filozofia przyrody a nauki przyrodnicze, Wyd. ATK, Warszawa 1998.

Macintosh J.J., Locke and Boyle on Miracles and God's Existence, w: Robert Boyle Reconsidered, red. M. Hunter, Cambridge University Press, Cambridge 1994, 193-214.

McMullin E., Ewolucja i stworzenie, tłum. z ang. J. Rodzeń, Kraków 1990, 42-50. 
Pałubicka A., Naturalizm i antynaturalizm, w: Filozofia a nauka. Zarys encyklopedyczny, red. Z. Cackowski, J. Kmita, K. Szaniawski, P.J. Smoczyński, Wrocław-Warszawa-Kraków-Gdańsk-Łódź 1987, 403-412.

Shanahan T., Teleological Reasoning in Boyle's Disquisition about Final Causes, w: Robert Boyle Reconsidered, red. M. Hunter, Cambridge University Press, Cambridge 1994, 177-192.

Sargent R.M., The Diffident Naturalist. Robert Boyle and The Philosophy of Experiment, University of Chicago Press, Chicago-London 1995.

Wojcik J., Robert Boyle and the Limits of Reason, Cambridge University Press, Cambridge 1997.

Wilson C., Epicureanism at the Origins of Modernity, Clarendon Press, Oxford 2008.

Życiński J., Bóg i ewolucja. Podstawowe pytania ewolucjonizmu chrześcijańskiego, Wyd. TN KUL, Lublin 2002.

\title{
THE PHILOSOPHY OF ROBERT BOYLE AND CONTEMPORARY CHRISTIAN THEISTIC NATURALISM
}

\begin{abstract}
Robert Boyle is the author of the original concept of mediation between the spheres of religious belief and scientific thought. This article presents Robert Boyle's selected topics of philosophy that illustrate his points of view on the issue of the relationship between scientific knowledge and faith. In the literature, the views Boyle qualifies as an example of a conception of two books: the Book of Nature and The Scripture, or the conception "God-of-the-gaps." In this paper I dispute this view and demonstrate that Boyle's conception the relationship between science and faith is similar but not identical to the contemporary theistic naturalism.
\end{abstract}

Keywords: Robert Boyle, faith and science, naturalism, theistic naturalism, nature and art 